\title{
Endothelial nitric oxide synthase gene polymorphisms (G894T) in diabetes mellitus in Egypt
}

\author{
El-baz ${ }^{1}$; Farouk $^{2}$; Tag Eldin²; Ezat $^{2}$ \\ ${ }^{1}$ Genetics Unit, Mansoura University \\ ${ }^{2}$ Research Institute (GEBRI),Sadat City
}

\begin{abstract}
Objective: Diabetic nephropathy (DN) is one of the major microvascular complications of diabetes. Genetic predisposition has been implicated in DN. The eNOS protein synthesizes nitric oxide constitutively via a reaction including the conversion of $\mathrm{L}$-arginine to $\mathrm{L}$-citrulline, which involves the transfer of five electrons provided by nicotinamide adenine dinucleotide phosphate The aim of this study is to evaluate the association of G894T polymorphisms of endothelial nitric oxide synthase(eNOS) gene with the development of diabetic nephropathy (DN) among Egyptian patients with type 1,2 diabetes mellitus in Egypt. Methods: Study subjects comprised 86 patients of type 2 diabetes with nephropathy, 23 patients of type 1 diabetes with nephropathy and 46 patients of type 2 diabetes without nephropathy. G894T genotypes was determined by SSP- PCR analysis. Results: Mutant T allele, GT and TT genotypes of G894TSNP had no significant frequencies in type 1,2 diabetic patients with nephropathy compared to those without nephropathy.. Conclusion: These findings indicate that G894T polymorphism of eNOS gene may be not considered as genetic risk factors for DN among Egyptian type1, 2 diabetic patients.
\end{abstract}

Abbreviations: T2DM: type 2 diabetes mellitus - DN: diabetic nephropathy eNOS : Endothelial nitric oxide synthase:- SNP: single nucleotide polymorphism- SSP-PCR: sequence specific primer- polymerase chain reaction.

Key words: eNOS gene - Type1, 2 diabetes - diabetic nephropathy.

\section{Introduction:}

Diabetic nephropathy (DN) is one of the major microvascular complications of diabetes and one of the leading causes of death among patients with diabetes (Chiarelli et al., 2009). Clinically, diabetic nephropathy is manifest as a progressive disease process that advances through characteristic stages. It begins with microalbuminuria (leakage of small amounts of albumin into the urine) and progresses to overt proteinuria. In a large proportion of these patients with diabetic nephropathy, renal function declines and continues to deteriorate until end stage renal disease (ESRD) is reached, and replacement therapy is indicated (Perkins et al., 2003; Brenner et al., 2004 and Perkins et al., 2007).

The etiology of DN is multifactorial and involves both environmental and genetic factors. A genetic predisposition, based on familial clustering of DN, has been implicated in the pathogenesis of nephropathy in type 2 diabetes mellitus (Sun J et al., 2004).

Nitric oxide (NO) synthesized by endothelial nitric oxide synthase (eNOS) plays an important role in regulation of endothelial function and in the control of blood pressure.

A healthy endothelium plays a core role in cardiovascular control (Drexler H,\& Horning B..2009).

Besides its regulatory functions on vasomotor tone and blood flow, endothelial NO is known to inhibit the platelet activation and modulate migration and growth of the vascular smooth $\mathrm{m}$ uscle (Marsden PA.et al.2007).

a point mutation of guanine to thymine at nucleotide position G894T in the endothelial nitric oxide synthase (eNOS) 
gene within exon 7 , resulting in a replacement of glutamic acid by aspartic acid at codon 298 (Glu298Asp), has been reported to be associated with Diabetic nephropathy(Knowles RG,\& Moncada S.2004).

Several lines of evidence suggest that endothelial damage could play a key role in the development of both micro- and macroangiopathy in diabetes. ( Moncada S, Higgs A.2002).

Endothelial dysfunction plays a key role in the pathogenesis of diabetic vascular disease, including diabetic nephropathy. Endothelial-derived nitric oxide synthase (eNOS) gene polymorphisms affect eNOS activity and are associated with endothelial dysfunction. (Ahluwalia TS et al.,2008 ). We evaluated the association of the constitutive endothelial nitric oxide synthase gene (eNOS) G897T polymorphism with types 1,2 diabetic nephropathy.

\section{Aim of the work:}

The aim of this study is to evaluate the association of G894T polymorphism of endothelial nitric oxide synthase (eNOS) gene with the development of diabetic nephropathy (DN) among Egyptian patients with types 1,2 diabetes mellitus in Egypt .

\section{Subjects and Methods:}

\section{Subjects:}

This study has included 109 subjects affected with diabetes typeI, II. They were recruited from the Internal Medicine Specialized Hospital and Nephrology Center, Mansoura University, Egypt in the period between January and September 2009. They were divided into 2 groups in relation to the presence of nephropathy which is defined as urinary albumin excretion rate $(\mathrm{AER})>30 \mathrm{mg}$ per day. The first group consists of 102 subjects affected with diabetes type II associated with nephropathy. Their mean \pm SD age was $58.7 \pm 6.43$ ranges from 45 to 75 years. They were in the form of 54(52.9\%) males and $48(47.1 \%)$ females. Of them 32 (31.4) were affected with microalbuminuria $(\mathrm{AER}=30-300 \mathrm{mg} / \mathrm{day})$, while the others $70(68.6 \%)$ showed macroalbuminuria (>300mg/day). The other group was affected with diabetes type II without nephropathy $(\mathrm{n}=100)$, their mean \pm SD age was 52.1900 \pm 8.31901 range from 34 to 75 years, their gender was in the form of 30 $(30.0 \%)$ males and $70(70.0 \%)$ females.

\section{Method:}

DNA extraction and purification

After obtaining informed consent from all cases and controls, venous blood samples (3 $\mathrm{ml}$ ) were collected on EDTA

(ethylenediamine tetra acetate) containing tubes, DNA was extracted promptly using DNA extraction and

purification kit (Gentra Systems, USA) according to manufacturer's instructions and then stored at $-200 \mathrm{C}$ till use.

\section{PCR amplification}

A set of primers was designed to amplify a 206 bp fragment including the missense Glu298Asp variant (G894T polymorphism) [5'-CAT GAG GCT CAG CCC CAG3'(foward) and 5'-AGT CAA TCC CTT TGG TGC TCA C-3' (reverse)]. The PCR fragment digested overnight at $37^{\circ} \mathrm{C}$

with the $\mathrm{MboI}$ restriction enzyme was separated by electrophoresis

on $2 \%$ agarosium gel and visualized by ethidum bromide staining. In the presence of a $\mathrm{T}$ nucleotide at position 894 corresponding to Asp 298, the 206 bp PCR product was cleaved into two fragments of 119 and $87 \mathrm{bp}$; whereas the presence of a $\mathrm{G}$ removed the restriction site recovering a single fragment of $206 \mathrm{bp}$

\section{Detection of amplified and digested products}

The entire reaction volume plus $5 \mu 1$ of bromophenol blue track dye were loaded into 2\% agarose gel (Boehringer Mannheim) containing ethidium bromide. Gels were electrophoresed for 30 minutes at $100 \mathrm{~V}$, photographed under UV light (320 $\mathrm{nm})$ and then scored for the presence or absence of an allele specific band. 
Statistical analysis: Data were processed and analyzed using the Statistical Package of Social Science (SPSS, version 10.0). The frequency of studied allelic polymorphisms were compared between groups by using Fisher's exact test (modified Chi square test) and. A value of $\mathrm{P}<0.05$ was considered to be significant.

\section{Results}

Table (1): Descriptive data of studied cases of types 1, 2 diabetes mellitus with nephropathy.

\begin{tabular}{||lr||}
\hline & Cases \\
\hline \hline Number & 109 \\
Type 1 & 23 \\
Type 2 & 86 \\
Age (Years) & \\
$\quad$ Mean \pm SD & $55.75 \pm 9.40$ \\
$\quad$ Median & 56.00 \\
Range & $26.00-75.00$ \\
Sex (M/F) & $(59 / 50)$ \\
Weight (Kg) & $87.86 \pm 12.77$ \\
Duration of diabetes (years) & $16.89 \pm 5.94$ \\
Family history (positive/negative) & $85 / 24$ \\
Consanguinity (positive/negative) & $20 / 89$ \\
Glycosylated hemoglobin (HbA1c, \%) & $6.10 \pm 1.59$ \\
Creatinine (Cr, mg/dl) & $3.31 \pm 2.05$ \\
Cholesterol (mg/dl) & $212.36 \pm 65.59$ \\
Triglyceride (TG, mg/dl) & $199.20 \pm 88.84$ \\
High density lipoprotein (HDL, mg/dl) & $140.98 \pm 58.78$ \\
Low density lipoprotein (LDL, mg/dl) & $36.92 \pm 12.03$ \\
Microalbuminurea/ Macroalbuminurea & $31 / 78$ \\
Blood pressure & \\
$\quad$ Mild hypertension & $46(69.7 \%)$ \\
$\quad$ Moderate hypertension & $100(91.7 \%$ \\
$\quad$ Severe hypertension & $50(45.9 \%)$ \\
Diabetic retinopathy & \\
Diabetic neuropathy & $50(45.9 \%)$ \\
Ischemic heart disease & $19(17.4 \%)$ \\
\hline \hline
\end{tabular}


Endothelial nitric .....

Table (2): Comparison between all cases with type 1, 2 diabetes with nephropathy and controls regarding their allele frequency and genotype distribution of G894T polymorphisms of eNOS gene.

\begin{tabular}{||cccccc||}
\hline \hline \multicolumn{3}{|c}{ G894T } & \multicolumn{2}{c}{ Genotypes } & \multicolumn{3}{c||}{ Alleles } \\
& $\mathrm{GG}$ & $\mathrm{GT}$ & $\mathrm{TT}$ & $\mathrm{G}$ & $\mathrm{T}$ \\
\hline $\begin{array}{c}\text { All cases } \\
(\mathrm{n}=109)\end{array}$ & $70(64.2)$ & $24(22.0)$ & $15(13.8)$ & $164(75.2)$ & $54(29.5)$ \\
$\begin{array}{c}\text { H. controls } \\
(\mathrm{n}=46) \\
\mathrm{P}\end{array}$ & $35(67.1)$ & $7(15.2)$ & $4(8.7)$ & $447(71.9)$ & $175(28.1)$ \\
\hline \hline
\end{tabular}

$\mathrm{n}=$ number of cases

$(\%)=$ percentage of cases

Table (3): Comparison between type 1 diabetes with nephropathy and controls regarding their allele frequency and genotype distribution of G894T polymorphisms of eNOS gene.

\begin{tabular}{|c|c|c|c|c|c|}
\hline \multirow[b]{2}{*}{ G894T } & \multicolumn{3}{|c|}{ Genotypes } & \multicolumn{2}{|c|}{ Alleles } \\
\hline & $\begin{array}{c}\mathrm{GG} \\
\mathrm{n}(\%)\end{array}$ & $\begin{array}{ll}\mathrm{GT} & \\
& \mathrm{n}(\%)\end{array}$ & $\begin{array}{c}\mathrm{TT} \\
\mathrm{n}(\%)\end{array}$ & $\begin{array}{c}\mathrm{G} \\
\mathrm{n}(\%)\end{array}$ & $\begin{array}{c}\mathrm{T} \\
\mathrm{n}(\%)\end{array}$ \\
\hline $\begin{array}{c}\text { Type 1 } \\
(\mathrm{n}=23)\end{array}$ & $16(69.6)$ & $4(17.4)$ & $3(13.0)$ & $36(75.2)$ & $10(29.5)$ \\
\hline $\begin{array}{c}\text { controls } \\
(\mathrm{n}=46)\end{array}$ & $35(67.1)$ & $7(15.2)$ & $4(8.7)$ & $77(71.9)$ & $15(28.1)$ \\
\hline $\mathrm{P}$ & 0.57 & 1.00 & 0.67 & 0.48 & 0.48 \\
\hline
\end{tabular}

$\mathrm{n}=$ number of cases

$(\%)=$ percentage of cases

Table (4): Comparison between type 2 diabetes with nephropathy and controls regarding their allele frequency and genotype distribution of G894T polymorphisms of eNOS gene.

\begin{tabular}{||cccccc||}
\hline \hline \multirow{3}{*}{ G894T } & \multicolumn{2}{c}{ Genotypes } & \multicolumn{3}{c||}{ Alleles } \\
& $\mathrm{GG}$ & $\mathrm{GT}$ & $\mathrm{TT}$ & $\mathrm{G}$ & $\mathrm{T}$ \\
& $\mathrm{n}(\%)$ & $\mathrm{n}(\%)$ & $\mathrm{n}(\%)$ & $\mathrm{n}(\%)$ & $\mathrm{n}(\%)$ \\
\hline $\begin{array}{c}\text { Type } 2 \\
(\mathrm{n}=86)\end{array}$ & $54(62.8)$ & $20(23.3)$ & $12(14.0)$ & $128(75.2)$ & $44(29.5)$ \\
$\begin{array}{c}\text { controls } \\
(\mathrm{n}=46) \\
\mathrm{P}\end{array}$ & $35(67.1)$ & $7(15.2)$ & $4(8.7)$ & $77(71.9)$ & $15(28.1)$ \\
\hline
\end{tabular}

$\mathrm{n}=$ number of cases

$(\%)=$ percentage of cases 

Table (5): Comparison between type 1 diabetes with nephropathy and type 2 diabetes with nephropathy regarding their allele frequency and genotype distribution of G894T polymorphisms of eNOS gene.

\begin{tabular}{||cccccc||}
\hline \hline G894T & Genotypes & & \multicolumn{2}{c||}{ Alleles } \\
& $\mathrm{GG}$ & $\mathrm{GT}$ & $\mathrm{TT}$ & $\mathrm{G}$ & $\mathrm{T}$ \\
& $\mathrm{n}(\%)$ & $\mathrm{n}(\%)$ & $\mathrm{n}(\%)$ & $\mathrm{n}(\%)$ & $\mathrm{n}(\%)$ \\
\hline $\begin{array}{c}\text { Type } 1 \\
(\mathrm{n}=23)\end{array}$ & $16(69.6)$ & $4(17.4)$ & $3(13.0)$ & $36(75.2)$ & $10(29.5)$ \\
Type 2 & $54(62.8)$ & $20(23.3)$ & $12(14.0)$ & $128(71.9)$ & $44(28.1)$ \\
$(\mathrm{n}=86)$ & & & & 0.7 & 0.7 \\
$\mathrm{P}$ & 0.62 & $\mathbf{0 . 7 7}$ & $\mathbf{1 . 0 0}$ & 0 \\
\hline \hline
\end{tabular}

$\mathrm{n}=$ number of cases

$(\%)=$ percentage of cases

Table (6): Comparison between type 1 diabetes with nephropathy, type 2 diabetes with nephropathy and controls regarding their allele frequency and genotype distribution of G894T polymorphisms of eNOS gene.

\begin{tabular}{|c|c|c|c|c|c|}
\hline \multirow[b]{2}{*}{ G894T } & \multicolumn{3}{|c|}{ Genotypes } & \multicolumn{2}{|c|}{ Alleles } \\
\hline & $\begin{array}{c}\mathrm{GG} \\
\mathrm{n}(\%)\end{array}$ & $\begin{array}{l}\text { GT } \\
\mathrm{n}(\%)\end{array}$ & $\begin{array}{c}\mathrm{TT} \\
\mathrm{n}(\%)\end{array}$ & $\begin{array}{c}\mathrm{G} \\
\mathrm{n}(\%)\end{array}$ & $\begin{array}{c}\mathrm{T} \\
\mathrm{n}(\%)\end{array}$ \\
\hline $\begin{array}{l}\text { Type } 1 \\
(\mathrm{n}=23)\end{array}$ & $16(69.6)$ & $4(17.4)$ & $3(13.0)$ & $36(75.2)$ & $10(29.5)$ \\
\hline $\begin{array}{c}\text { Type } 2 \\
(n=86)\end{array}$ & $54(62.8)$ & $20(23.3)$ & $12(14.0)$ & $128(71.9)$ & $44(28.1)$ \\
\hline $\begin{array}{c}\text { Controls } \\
(n=46)\end{array}$ & $35(76.1)$ & $7(15.2)$ & $4(8.7)$ & 77 & 15 \\
\hline $\mathrm{P}$ & 0.62 & 0.77 & 0.92 & 0.43 & 0.43 \\
\hline
\end{tabular}

$\mathrm{n}=$ number of cases

$(\%)=$ percentage of cases 



\section{$\begin{array}{llllllll}M & 1 & 2 & 3 & 4 & 5 & 6 & 7\end{array}$}

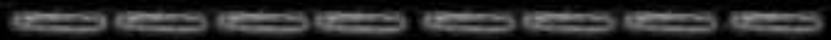

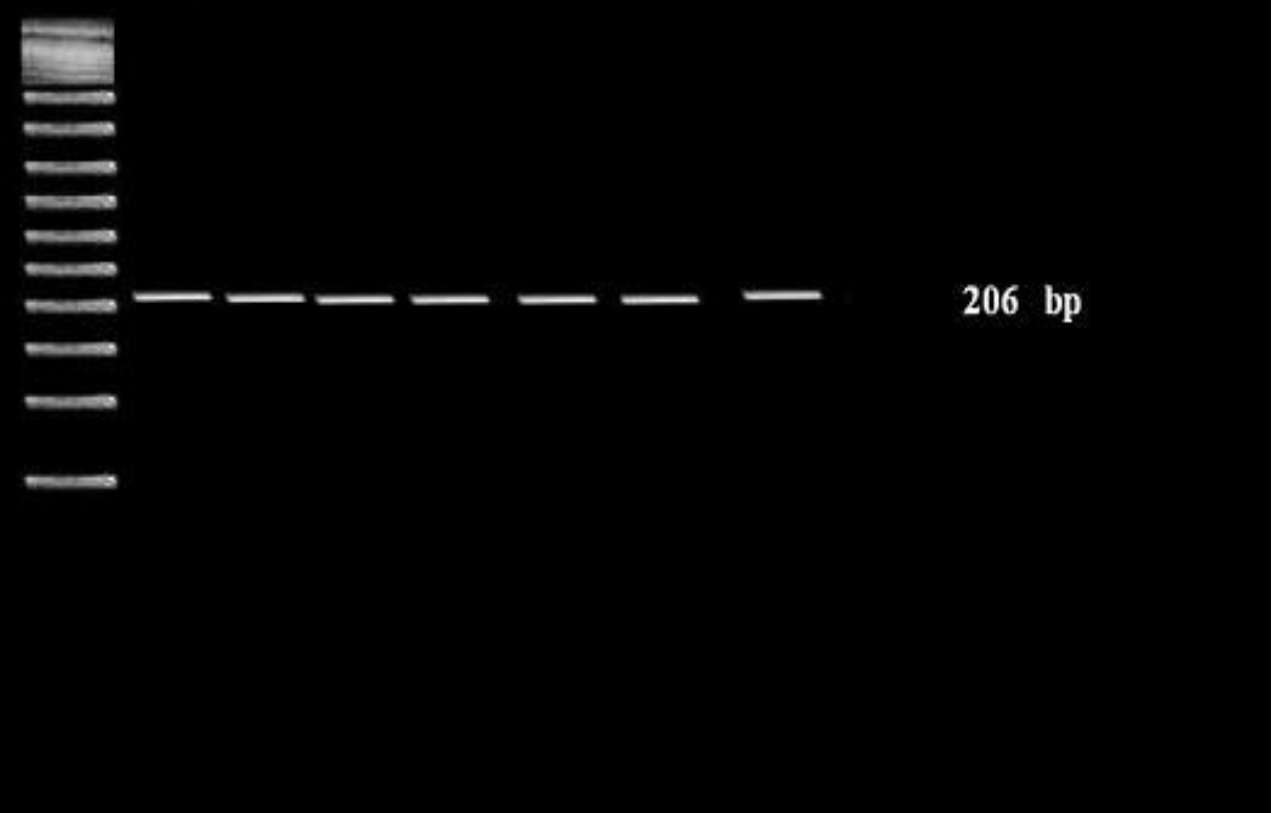

Fig (1): PCR amplification of G894T polymorphism of eNOS gene PCR product of G894T polymorphism have band size $206 \mathrm{bp}$. wild type GG is found which appears at $206 \mathrm{bp}$ in all lanes

Lane M: DNA size marker $50 \mathrm{bp}$ 



\section{M $1120 \begin{array}{lllllll}1 & 2 & 3 & 4 & 5 & 6 & 7\end{array}$}

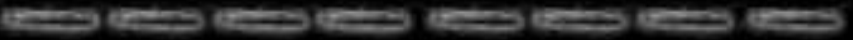

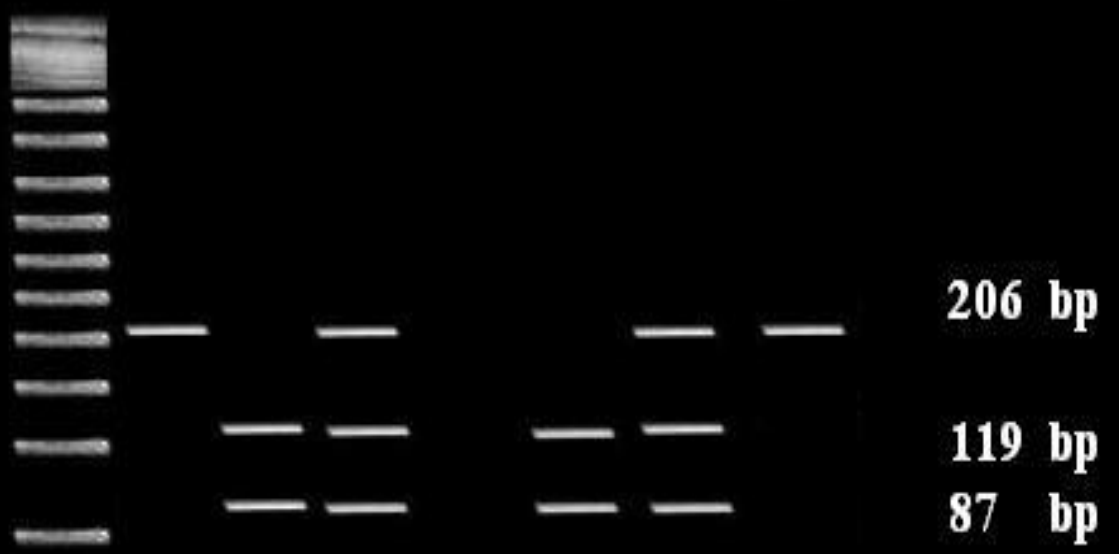

Fig (2): enzymatic digestion of G894T polymorphism of eNOS gene. wild type GG is found which appears at 206 bp only lanes 1 and 7

Digestion of PCR product of G894T polymorphism of eNOS gene using MboI enzyme. which digests the 206- bp fragment into 119- and 87- bp frgments(heterozygous mutated genotype GT which has 206, 119, 87 bp fragments lanes 3 and 6 ) (homozygous mutated genotype TT is found which has 119, $86 \mathrm{bp}$ fragments lanes 2and 5)

Lane M: DNA size marker $50 \mathrm{bp}$ 



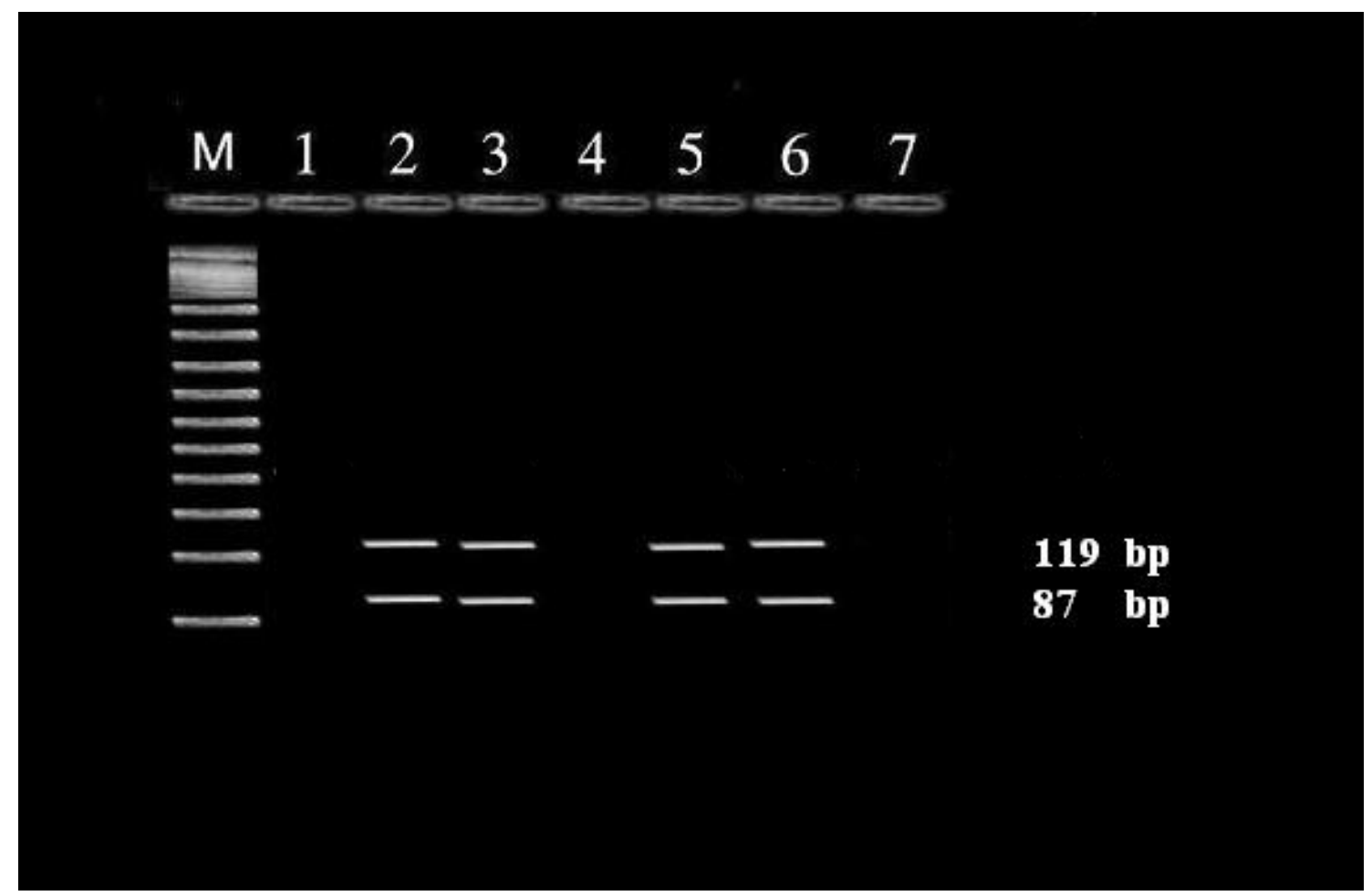

Fig (3): enzymatic digestion of G894T polymorphism of eNOS gene. Digestion of PCR product of G894T polymorphism of eNOS gene using MboI enzyme. which digests the 206- bp fragment into 119- and 87- bp frgments (homozygous mutated genotype TT is found which has $119,86 \mathrm{bp}$ fragments lanes $2,3,5$ and 6)

Lane M: DNA size marker $50 \mathrm{bp}$ 



\section{Discussion:}

Our data showed that homozygous mutated TT genotype, mutant $\mathrm{T}$ allele of G894T polymorphism had not significant frequency among cases of types 1, 2 diabetes with nephropathy compared to controls . Thus TT genotype and $\mathrm{T}$ allele may be not considered as genetic risk factors for diabetic nephropathy.

The study of Anne Zanchiet al. (2007) that included 82 American type 1 diabetics with nephropathy and 85 controls diabetic patients without nephropathy showed that the frequencies of eNOS G894T gene variant genotypes and alleles in the patients with DN patients were not significant among cases $(\mathrm{P}=0.37)$ Anne Zanchiet al. (2007). In a study of a sample ofAmerican patients of type 1 diabetes mellituswith diabetic nephropathy found that The frequency of TT homogenetic type and Tallele (28.21\%, $53.85 \%$ ) was higher in patients of type 1 diabetes mellitus with diabetic nephropathy than controls $(17.54 \%, 31.58 \%)$ Sun et al., (2007). Alsoobserved that amongAmerican population, markedly elevated mutation was observed in patients with diabetic nephropathy as compared with normal people $(20.8 \%$ vs $7.3 \%$, ).Also, Noiri et al. (2005)

In a study of Hua Caiet al. that included 574 Australian diabetic patients with nephropathy and controls 324 diabetic patients without nephropathy showed that $48 \%$ patients with diabetic nephropathy had eNOS gene mutation, $(P=0.30)$ Hua Caiet al. (1998). The genotype distribution and allele frequencies between patients $(\mathrm{GG}=51.9 \%, \mathrm{GT}=40.6 \%, \mathrm{TT}=$ $7.5 \%, \mathrm{G}$ allele $72 \%$, $\mathrm{T}$ allele $28 \%$ ) and not different between men and women ( $\mathrm{P}=$ 0.700). The ecNOS TT and TG genotypes were not associated with age, age at onset of documented diabetes, BMI, systolic and diastolic blood pressures (BPs), lipid pro file plasma creatinine and glycosylated hemoglobin ( $\mathrm{HbA} 1 \mathrm{c})$ levels, or urinary albumin index (UAI: albumin/creatinine ratio).

They reported that homozygous mutated TT genotype, mutant $\mathrm{T}$ allele of G894T polymorphism had significant frequency among cases of types 1, 2 diabetes with nephropathy compared to controls . Thus TT genotype and T allele may be considered as genetic risk factors for diabetic nephropathy.

The study of Tarunveer Singhet al..that included 195India type 2 diabetics with nephropathy and controls 255diabetic patients without nephropathy showed that the frequencies of eNOS G894T gene variant genotypes and alleles in the patients with DN patients with nephropathywere significantly higher than those in patients without nephropathyp $=0.03$

Tarunveer Singh et al.( 2008). In a study of a sample of India patients of type 2 diabetes mellituswith diabetic nephropathy Sun and colleagues found that The frequency of TT homogenetic type and Tallele $(28.21 \%, 43.85 \%)$ was significantly higher in India patients of type 2 diabetes mellitus with diabetic nephropathy thanpatients without nephropathy $(17.54 \%$, $31.58 \%$ )

The genotype distribution and allele frequencies between patients $(\mathrm{GG}=38.5 \%$, $\mathrm{GT}=33.3 \%, \mathrm{TT}=28.2 \%, \mathrm{G}$ allele $56.15 \%$, $\mathrm{T}$ allele $43.85 \%$ )

Our study showed that there were no significant differences in genotype distribution of G894T polymorphism of eNOS gene among types 1,2 diabetic patients with macroalbuminurea compared to those with microalbuminurea .

Interestingly, the frequency of homozygous mutated TT genotype of G894T polymorphism of eNOS gene was no significant among Cases with 
gender,among types $1,2(\mathrm{p}=0.31), \mathrm{P}=0.94$ respectively

We noted that, there is no significant difference among cases of diabetes types 1, 2 with nephropathy regarding their genotypes of G894Tpolymorphism of eNOS gene when they classified to subgroups according to parental consanguinity, $\mathrm{p}=0.24, \mathrm{P}=0.38$ respectively

Our data indicate that no significant difference between positive and negative family history subgroups of types 1, 2 diabetic patients with nephropathy regarding their genotypes of G894T polymorphism.

$$
\mathrm{p}=0.47, \mathrm{P}=0.86 \text { respectively }
$$

Our data showed that homozygous mutated TT genotype, mutant $\mathrm{T}$ allele of G894T polymorphism had a significantly higher frequency inischemic heart disease (coronary heart disease) among cases of type 1 diabetes with nephropathy compared tocases of type 2 diabetes with nephropathy ( $\mathrm{p}=0.02, \mathrm{P}=0.042$ respectively). Thus TT genotype and $\mathrm{T}$ allele may be considered as genetic risk factors forcoronary heart disease .

Our study indicated that there were no association betweenG894T polymorphism and hyperlipidemia among subgroups of patients with types

1, 2 diabetes which were classified regarding their lipid profile (cholesterol, triglycerides, HDL and LDL).

Conclusions: Our findings indicate that G894T polymorphisms of eNOSgene may be not considered as genetic risk factors for DN among Egyptian type1, 2 diabetic patients.

\section{References:}

1 - Adler S. 2004 Diabetic nephropathy: Linking histology, cell biology, and genetics. Kidney Int.;66(5):2095-106.
2 - Ahluwalia TS, Ahuja M, Rai TS, Kohli HS, Sud K, Bhansali A, Khullar M Mol Cell Biochem. 2008 Jul;314(1-2):9-17.

3 - Andrew PJ, Mayer B.1999 Enzymatic function of nitric oxide synthases. Cardiovasc Res;43:521-31. cells exposed to nitric oxide in vitro.

4 - Chiarelli F, Gaspari S, Marcovecchio ML.2009 Role of growth factors in diabetic kidney disease. Horm Metab Res.;41(8):585-93

5 - Drexler H, Horning B. 2009 Endothelial dysfunction in human disease. $\mathrm{J}$ Mol Cell Cardiol, , 31(1): 51-60

6 - Hayden JM, Reaven PD. 2000 Cardiovascular disease in diabetes mellitus type 2: a potential role for novel cardiovascular risk factors.Curr Opin Lipidol.;11(5):519-28.

7 - Knowles RG, Moncada S.2004 Nitric oxide synthases in mammals. Biochem J, 298(Pt2): 249-258

8 - Marsden PA, Heng HH, Scherer SW, et al.2007, Structure and chromosomal localization of the human constitutive endothelial nitric oxide synthase gene. J Biol Chem; 268:17478-88.

9 - Moncada S, Higgs A. 1993The L-argininenitric oxide pathway. $\mathrm{N}$ Engl J Med ;329:2002-12.

10- Perkins BA, Ficociello LH, Ostrander BE, Silva KH, Weinberg J, Warram JH, Krolewski AS. 2007 ,Microalbuminuria and the risk for early progressive renal function decline in type 1 diabetes. $\mathrm{J}$ Am Soc Nephrol.;18(4):1353-61.

11- Southan GJ, Szabó C (1996). "Selective pharmacological inhibition of distinct nitric oxide synthase isoforms". Biochem. Pharmacol. 51 (4): 383-94

12 - Tanaka N, Babazono T. 2005, Assessing genetic susceptibility to diabetic nephropathy. Nephrology (Carlton),;10 Suppl:S17-21

13- Trevisan R, Viberti G. 1995, Genetic factors in the development of diabetic nephropathy. J Lab Clin Med.;126(4):3429.

14-Triplitt C and Alvarez CA. 2008, Best Practices for Lowering the Risk of Cardiovascular Disease in Diabetes. Diabetes Spectrum.;21:177-189.

15-Ziyadeh FN, Wolf G. 2008, Pathogenesis of the podocytopathy and proteinuria in diabetic glomerulopathy. Curr Diabetes Rev.;4(1):39-45. 


\title{
التعدد الجينى لجين تخليق أكسيد النيتريك فى مرضى السكر المصريين
}

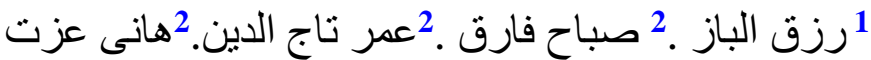

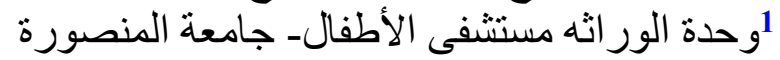 \\ 2معهد بحوث الهندسة الو راثية و التكنولوجيا الحيوية بالسادات الاندات
}

اعتلال الكلي السكري هو احد المضاعفات طويلة الامد الناتجة عن مرض السكري. يبدأ اعتلال

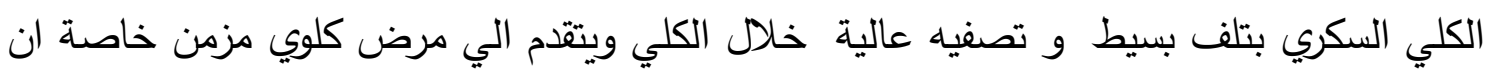

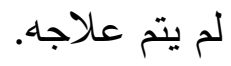
فالنسيج الداخلى للأوعيه الامويه يتحكم فى الأنقباض و الأنبساط عن طريق انتاج مواد تنظم

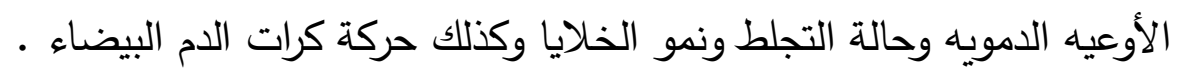

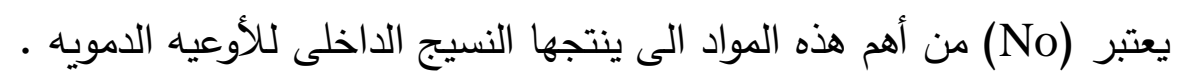

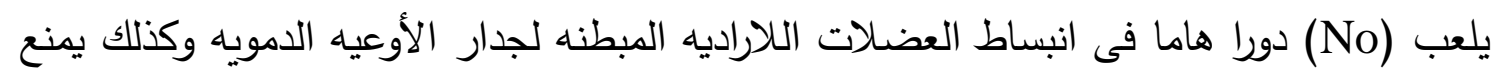

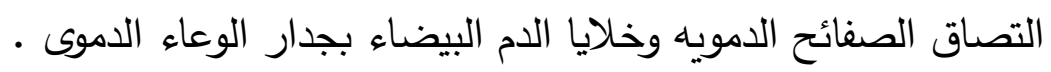

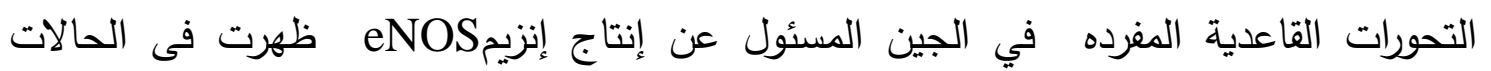
المرضيه لاعتلال الكلي السكري في بعض المجموعات العرقيه. يوجد واحد من التحورات القاعديه المفرده المعروفه وهو (جونين 894ثايمين). تم التخطيط لهذا البحث لدراسة تأثير التحورات القاعدية المفرده (جونين 894 ثايمين)علي القابلية الجينية لحدوث اعتلال الكلي السكري بين مرضي المصرين بالسكري النوعان الاول و الثاني.

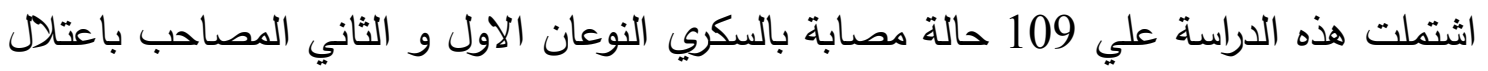

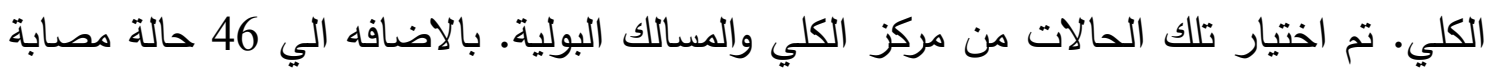
بالسكري النوع الثاني غير مصاحب باعتلال الكلي وتم اختيارهم من مستثفي الباطنه التخصصي.

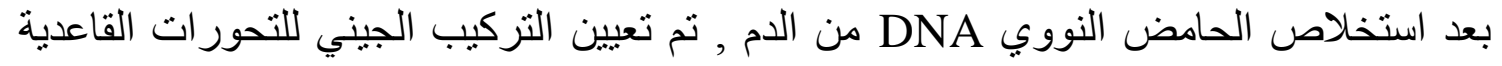
المفرده(جونين 894 ثايمين) لجين eNOS باستخدام تفاعل البلمره المتسلسل والتقطيع بانزيمات

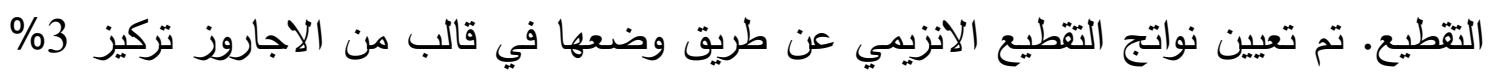

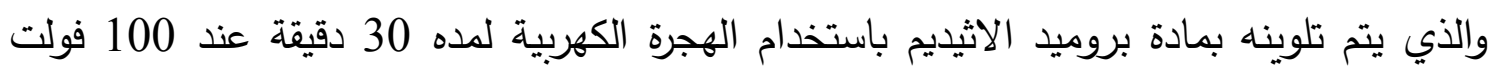


ثم تصوير القالب باستخدام الاشعة الفوق بنفجية وتم عمل صورة بافلام البولارويد لتسجيل النواتج. وجد أن... (-ن لا توجد نسبة احصائية معنويه بالتركيب الجيني( ثايمين ثايمين) الخاص بالتحور القاعدي المغرد

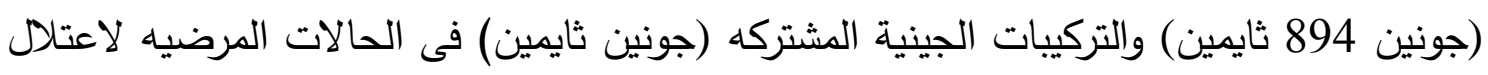
الكلي السكري لا يوجد فروق معنوية في نسب التحور ( جونين 894 ثايمين)عند تقسيم حالات السكري النوعان

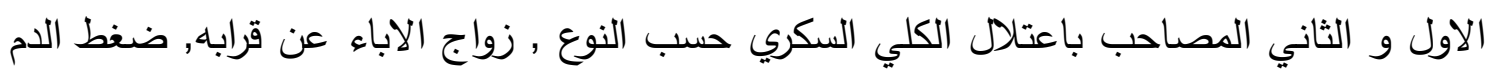

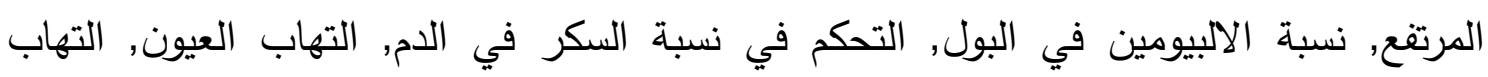

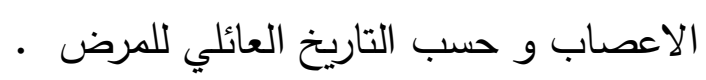

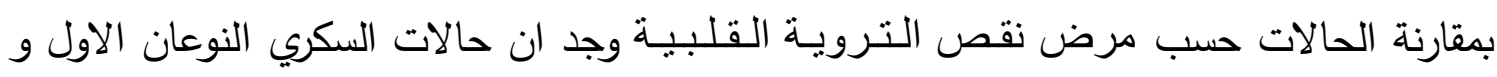
الثاني المصاحب باعتلال الكلي السكريا لديهم نسبة احصائية معنويه . 